\title{
Design como veículo de comunicação e linguagem
}

PATELLI, Enzo; Acadêmico do curso de Design Gráfico; Universidade Federal de Pelotas enzonze@hotmail.com

Orientador: BARROS, Roberta Coelho; Doutora; Universidade Federal de Pelotas

robertabarros@gmail.com

Palavras-Chave: Design, comunicação, linguagem, teoria

Resumo: Utilizando das discussões acerca do design de Daniel Portugal, Ivan Mizanzuk e Marcos Beccari em "Existe design?", além das observações a respeito de objetos, comunicação e sociedade de Marshall McLuhan ("Os meios de comunicação") e Deyan Sudjic ("A linguagem das coisas"), o artigo busca tentar entender o design como a linguagem presente na produção material ou cultural do homem. Discute a possibilidade dos objetos se comunicarem conosco através do design, assim como o design como linguagem ser passível de ser entendido apenas como língua, e não apenas através das mensagens que imbui nos objetos.

\section{Introdução}

Segundo Rafael Cardoso (2013), o design advém da industrialização, responsável por planejar e moldar a imensidão de produtos que passou a ser produzida, no que foi o início da era de consumo. O designer não apenas se preocupava com a eficiência, mas também com a aparência do que era ofertado ao público consumidor. Isso continuou até a década de 1930, segundo ele, onde o enunciado "a forma segue a função" acabou se tornando o núcleo da prática do design. Cerca de quarenta anos depois, Victor Papanek enfrenta essa ideia, discorrendo em seu livro Design for the Real World que a verdadeira preocupação e mote do design deveria ser a função social, e não a funcionalidade de produtos

(CARDOSO, 2013). Hoje em dia, entre as diversas camadas de interação que envolvem cada objeto produzido por nós e a ascensão das interações imateriais, o design não se resolve seguindo um único objetivo com aspirações de solução universal, seja no funcionalismo de 1930 ou na visão sociológica de Papanek (CARDOSO, 2013).

Embora hoje se projete uma maior variedade de objetos comparado a época da Revolução Industrial - alguns deles impensáveis para a época, e pouco táteis, como interfaces de software - o fato do design ser o meio pelo qual se moldam objetos do dia a dia não mudou. Hoje, inclusive, não é incomum ouvir juízos de valor sobre produtos na forma de frases como "este é um carro bom, com design", ou "que celular com design estranho", ou seja, fala-se de design "mais ou menos do mesmo modo que falamos da saúde de alguém" (MIZANZUK; BECCARI; PORTUGAL, 2013). Parece natural quando notamos que muito de nossas vidas são vividas e lembradas através de objetos - o computador comprado com o primeiro salário, o relógio herdado do avô, etc. Objetos não apenas marcam a passagem de tempo de nossa trajetória, mas também o que desejamos expressar para o mundo (SUDJIC, 2010). Mas, se objetos podem emitir mensagens a respeito de seus donos para outras pessoas, e são projetados através do design, então o design não é apenas um método de projeto para a confecção desses objetos - é também a linguagem pela qual eles podem se comunicar (SUDJIC, 2010). 
Se pensarmos no design como atividade puramente projetual, caímos num interessante paradoxo: sendo o design aquilo que se preocupa com as formas dos objetos, ele se torna um engodo, por não possuir um objeto específico com o qual se ocupa. Afinal, um engenheiro aeronáutico se preocupa com a forma de um avião mais eficientemente que um designer, assim como um alfaiate com ternos ou arquiteto com casas (MIZANZUK; BECCARI; PORTUGAL, 2013). Portanto, enxergar design como uma linguagem que comunica através das formas parece uma possibilidade distinta. McLuhan (1974) afirma que todo veículo de comunicação contém outro meio - a escrita, por exemplo, nada mais é do que o registro da fala. Por essa ótica, as formas que o design realiza, em si, são veículos de comunicação. Soa implausível num primeiro momento, mas basta pensarmos em tipografia. "As formas dos tipos transmitem níveis de significado que vão além do conteúdo literal das próprias palavras" (SUDJIC, 2010). Caso contrário, convites de casamento seriam confeccionados com Arial, Comic Sans ou Courier New sem resistência.

Tendo tudo isso em mente, há outros dois pontos a se pensar: qual é a linguagem que os objetos produzidos pelo design contém, e qual a função do designer ao entender que sua área de atuação é um meio comunicacional?

\section{Discussão}

A respeito dos objetos, eles se expressam através de textura, cor, tamanho e outros elementos formais (SUDJIC, 2010). Ou seja, um objeto vermelho expressa algo diferente que um objeto idêntico em todos outros aspectos, exceto que azul. No entanto, esta linguagem das formas não parece ser inerentemente ligada a seus significados e sim associada a eles pela sociedade. No design, também se recorre a associações ao dar forma a objetos:

\footnotetext{
Por exemplo, você sai, o sol está brilhando, e todos estão de acordo que isso é muito agradável. Mas quando se trata de ilustrar a umidade ou a secura, é diferente. Você tem que estabelecer uma relação. Isso tem que ser relacionado de alguma forma a algo que te dê um parâmetro. É preciso ter alguma pista visual. É assim que você mostra o seco e o molhado. [...] por exemplo, temos um padrão de pontos brancos num fundo preto, pode haver uma associação com gotas de chuva. (RAND apud KROEGER, 2010, p. 35)
}

Essas associações são mutáveis através da passagem de tempo. Ambos fatos são facilmente provados ao observamos a música "Entrada dos Gladiadores", do compositor tcheco Julius Fučík. Originalmente inspirada, conforme o nome sugere, pela cultura romana e belicismo, foi projetada como uma marcha militar. Treze anos depois e rearranjada para bandas menores, ela foi regularmente comprada e usada por circos na América, hoje sendo imediatamente identificada como "aquela música do palhaço de circo" devido a esse uso (STUDWELL; CONRAD; SCHUENEMAN, 1999). A velocidade do ciclo consumo-descarte atualmente torna difícil notar tais transformações, visto que raramente as mesmas pessoas convivem com os mesmos objetos por tanto tempo (CARDOSO, 2003). Por outro lado, é notável o quanto se ressignifica produtos culturais regularmente na internet, o que nos leva 
a notar mais um diferencial da nossa era: os objetos são polissêmicos, e de mais de uma maneira. Por exemplo, os óculos deixaram de ser estritamente medicinais para serem objetos de moda, enquanto os telefones assimilaram a câmera fotográfica, o toca "discos", o correio eletrônico, etc (SUDJIC, 2010).

Portanto, um objeto criado pelo homem contém muitas mensagens, seja através do contexto sócio temporal no qual foi produzido, seja através de suas funções, aparência ou simplesmente da percepção que um determinado público lhe atribui (independentemente da intenção do criador ou não). Logo, não basta ao designer, hoje, resolver questões formais ou funcionais, mas também adequadamente trabalhar o que seu objeto deve comunicar como um contador de histórias (SUDJIC, 2010). Partindo desse ponto de vista, um designer não apenas está tornando aparente que determinado refrigerante é barato ou mais saudável (seja verdade ou não) ao utilizar certos elementos formais em seu rótulo, ele está contribuindo com a construção coletiva, dentro da sociedade na qual a bebida circulará e através do sistema econômico vigente, da narrativa maior que caracteriza a identidade da comunidade em que participa. Não que aquele que trabalha com design, por profissão, seja responsável por moldar a sociedade, visto que não há como garantir como os receptores de uma mensagem reagirão a ela, e também por não ser o único criando objetos.

Essa subjetividade que cerca a comunicação que ocorre sem palavras, dependente de tantas variáveis para sequer ser percebida ou atingir alguém, também pode ajudar a explicar o quão difícil é definir design, ou ao menos falar sobre ele. Ninguém vê um design. Se vê ações ou objetos que são associadas a design. Mas também só se pode associar algo a design quando se parte da prerrogativa de que ele existe em primeiro lugar - e isto precisa acontecer sem vermos, ouvirmos ou tocarmos "no" design (MIZANZUK; BECCARI; PORTUGAL, 2013). Algo similar ocorre com outros meios de comunicação: podemos ouvir uma canção em islandês, sermos afetados emocionalmente por ela, atribuir-Ihe significados e ideais, e sequer saber que ela foi composta numa língua já existente e cuja letra já possui uma mensagem embutida. E mesmo que isso nos seja dito, aceitamos que é daquela forma que islandês soa, mas não temos uma garantia imediata de que este é o caso.

Também é importante citar que ao aceitarmos o design como uma língua ou meio de comunicação, concedemos que design é um objeto em si, já que

\footnotetext{
[...] o bom design é também um prazer em si mesmo. A qualidade estética e escultural de um copo ou uma cadeira e a elegância intelectual de uma interface são expressões criativas intrinsecamente apreciáveis. Como também a elegância com que um programa de software interage com seus usuários. (SUDJIC, 2010, p. 50)
}

Assim sendo, pode se pensar no design como uma sintaxe de comunicação material, organizando e veiculando conteúdos através de produtos realizados pelo homem, que também pode ser apreciado em si, independentemente da mensagem (similar a poesia parnasiana), mesmo que seja dependente da relação produto-mensagem para ser percebido. 


\section{Referências}

CARDOSO, Rafael. Design para um mundo complexo. São Paulo: Cosac Naify, 2013.

MCLUHAN, Marshall. Os meios de comunicação como extensões do homem. São Paulo: Cultrix, 1974.

MIZANZUK, Ivan; PORTUGAL, Daniel B.; BECCARI, Marcos. Existe design?: indagações filosóficas em três vozes. Teresópolis: $2 A B, 2013$.

KROEGER, Michael. Conversas com Paul Rand. São Paulo: Cosac Naify, 2010.

STUDWELL, William E.; CONRAD, Charles P.; SCHUENEMAN, Bruce R. Circus Songs An Annotated Anthology. NY: The Haworth Press, 1999.

SUDJIC, Deyan. A linguagem das coisas. Rio de Janeiro: Intrínseca, 2010. 